\title{
Effect of Using Twitter in Teaching Parasitology in King Abduaziz University, Jeddah, Saudi Arabia
}

\author{
Najia A. Al-Zanbagi \\ Biology Department, Science College, King Abdulaziz University, Jeddah, Saudi Arabia
}

\begin{abstract}
The evolution of Social Web, particularly Social Media makes users interaction with Internet massive ideal proceeding. Web technologies have completely improved the Internet dynamics and allowing users to originate texts, images or video as well as to share and participate through huge geographical limits. This research trial explores the Saudi girls Parasitology student' behavior, understanding and effectiveness toward using Twitter in supporting learning and teaching aims. A main target was to raise discussion among students and promote learning via supporting student time on goal. Our innovative attempt followed guidelines lay in the Learning and Teaching such as Communicative Action Theory to increase the student education experience through strong connections and enlarge content sharing between girl students, for the sake of building social collaborative learning community. By using this method, we found different girl student comprehension of using Twitter, some have very positive views to be as a tool for supporting lectures while some views consider twitter have small interest to the students own learning.
\end{abstract}

Keywords: Twitter, Parasitology, Saudi Arabia, Social Media, Communicative Action theory,

\section{Introduction}

The evolution of Social Web makes huge paradigm shift and nowadays life is impossible without the technologies such as computer, smart phone, tablet PC and others, in all cultures people have grown so familiar to use these tools for their social activities that it is difficult to imagine life without them. The social networking tools such as Facebook, Twitter, YouTube, Google+ and blogs permits the online communication and also collaborates the work between participants. By participating in the social networks, now the computer users all over the world are cooperating in a new method of learning which allowed to make reshaping for all information and culture as well as to inform how initiate and cooperate content between individuals groups and societies (Bianco, 2009; Somerville and Brar, 2010; Kassens-Noor 2012). Learning by using computer mediated communication $(\mathrm{CMC})$ in the world allows students and their teachers to enjoy their jobs outside the classrooms (Wakefield et al., 2011; Reed, 2013).

In 1991, Lave and Wenger dowel the term "Communities of Practice" and gave its definition related to those people who hold the process of collective learning using shared domain of human effort (Wenger, 2006), which mean that Communities of Practice "CoP" is a community where learning include everyone (Wakefield et al., 2011). Learning by using computers affected the teacher's communication planning in classroom and required many to rethink in way of teaching (Neo \& Neo, 2004). Wakefield and Warren (2012) found that tools as blogs and microblogs permits teachers to induce free-flowing lifelike conversations outside class community which help the learning shape making it more authentic and real. They declare that this makes learners as part of $21^{\text {st }}$ century community by using technology for learning, the viewpoints are exchanged, collaboration are noticed, explanation are posted and experiences are participated (Wakefield et al., 2011)

Reed (2013) reported that although there are many websites and blogs still debating and encouraging the utilizing of Twitter in education, few published research related to how much social media assists education and learners and increase the student experience (Junco et al., 2011; Kassens-Noor 2012). However, research explains the student's integrating using various tools depending on individual choice to create their own personal learning environments (Dabbagh \& Kitsantas 2011; Hall 2009). Twitter allows teachers to readily examine how it may increase the innovative teaching process that promote classroom communication (Parry, 2008) and allow the instructors to know those students that their voices not heard (Rankin, 2009). Twitter users share the brief updates of 140 characters, interchange cosine direct messages with 
others, remarked and repost enjoyable tweets from others, participate in pictures, video, and Web links. International community of users permits participants to remain joined with their existing followers and entice more followers (Wakefield \& Warren, 2012).

According to Reed (2013) who mentioned that Anderson and Haddard (2005) found that comparing face-to-face learning, females experienced better understood deep education, when they get learning online. The participants said that they were greater capable to be their sound audible online than in the classroom which was better realized thoroughly education (Palloff and Pratt, 2007). However, this demand has since been misbelieve by other researchers (Gunawardena, 1995; Tu, 2002) who dispute that quality of computer mediated communication (CMC) can be knew similar to or stronger than communication in face-to face classrooms where social signs such as body language and facial expressions are existing. Social existence has been positively correlated with comprehend learning and course satisfaction (Gunawardena \& Zittle, 1997; Richardson \& Swan, 2003; Lowenthal, 2009). Other factor linked with social aspect is recognized interaction (Gunawardena, 1995; Kim et al., 2011). Some learners may be inconvenient with social communication, while others may not, but request to exceed against determined standard for individual cause (Wakefield \& Warren, 2012). When learners attract in public interaction, that behavior supports the effort feeling of being there jointly with other learners - sense of being part of social community. Contravention and inability to share ends the efficiency of communicative actions possessed by students. Teachers, moderators, and participants in the computer mediated communications (CMCs) all assist assimilation social existence (Gunawardena, 1995; Tu, 2002).

The literature appears confusing results on males and females learning research in computer-mediated environments. Some studies have preferable enlarge education in males, others have favored females, while still others record no statistically significant sex variation. For instance, Barrett and Lally (1999) reported that males in an online course were very socially effective and recorded more than females. By contrast, Anderson and Haddard (2005) found that females felt they educated more deeply online when contrasted with face-to-face method. A research on 1997 reported that gender played no role and both sexes showed similar use of online learning environment (Ory et al., 1997). A Twitter study as learning environment should give light on its usefulness to assist communicative actions prepared towards education and support the field better understand if there are variations in the role discourse plays for males and females in online setting. In United States, the demographic studies mentioned that 55\% of Twitter users are female (Quantcast, 2010) and 56\% of Facebook users are women who becoming more involved in using technology and social media, at least in non-educational case (Smith, 2010; Wakefield et al., 2011).

This article displayed to explore the Parasitology girls student's attitudes, understandings and relations in using Twitter application in two semesters for supporting learning and teaching the parasitic information in King Abdulaziz University, Jeddah, Saudi Arabia. There were many objectives for this trial, firstly to improve learning for Parasitology subjects, to motivate ability of students for getting information, to use Social Media in useful ways, to inform Saudi community about parasites and parasitic diseases and finally to introduce new method for getting marks.

\section{MATERIALS AND METHODS}

\section{Creating Twitter Account:}

An account named "We_Love_Para" was created and it was under the responsibility of the course teacher Prof. Dr. Najia A. Al-Zanbagi (Para is a short name of Parasitology). The girls students were asked to tweet using this account after every course Parasitology lectures which were scheduled in two days per a week for one semester of the year. This account was continued for every teaching semesters and was effective by the course girls students till the second term of 2016. The Parasitology course account "We_Love_Para" still active up to now.

\section{Strategy for Tweeting:}

Every girl student in the course was worked individually, and after the course lecture was finished, all students were asked to tweet using our Arabic language. Students should tweet about the subject explained in that day under the supervision of the course teacher who received and revised these tweets via WhatsApp application. The course teacher was firstly started tweets in the designed subject then followed by the student's tweets. The Arabic tweets of subject information should be new and useful and preferred to be accompanied by photo or film (Figure 1). This activity was considered as additional activity in the course, there was limited time for tweeting as well as there were marks according to which student tweets first. 


\section{Effectiveness Announcement:}

At the end of every semester, an educational exhibition was held in the main hall of Science College, King Abdulaziz University, Girls campus to present all efforts done by the course girl students. Exhibition announcement including the activity name and the dated times was distributed in the Girls campus (Figure 2). During the event, every student had to show the visitors her effort and general evaluation was done from the exhibition visitors and the course teacher.

\section{RESULTS}

At period of two semesters which were the first of 2015 and the second of 2016, the Twitter application was used as an extra activity for girl students in Parasitology course. In $1^{\text {st }}$ semester of 2014/2015, the total student number was 9 students, while in in the $2^{\text {nd }}$ semester $2015 / 2016$, they were only two students. The first tweet was on $16^{\text {th }}$ September 2014, the tweets were completed until $14^{\text {th }}$ March 2016 using 149 photos and 30 educational films. Other semesters of 2015 and 2016, the course not registered by students.

The total tweets was 375 tweets during that period and the @Student 1 was the most student made tweets as $20.3 \%$, while some students showed no activity in tweets (Table 1, Figure 3). Those students use this activity will get $20 \%$ out of $100 \%$ in the final evaluation.

Regarding the effect of using this activity in the student's grade in the course of Parasitology, it was clear that no correlation between the student tweets number and her grade in the final evaluation of Parasitology course, that some student who showed no activity in tweeting, they got good evaluation. For those students who practiced in using Twitter, mostly it raised their final evaluation in the course as well as it gave them more experience and they became more active and confident (Table 1, Figure 3)

In the point of the categories of Re-tweets from people in Twitter for the Parasitology students tweets, the highest number was in the range $>4$ re-tweets which was $109(41.1 \%)$, while the liked-tweets was $215(62.9 \%)$. The minimum number was in category of $<9$ that was $2(0.8 \%)$, and no liked-tweets in that category (Table 2, Figure 4). Regarding the most tweets had more re-tweeted and liked-tweet was for that related to the information of animal relationships such as commensalism, symbiosis and parasitism (Figure 5).

\section{DISCUSSION and CONCLUSION}

Although the trial of using this social application (Twitter) in teaching scientific subject in Biology Department was considered innovative technique in teaching, only $66.7 \%$ of the Parasitology students $(n=9)$ used Twitter as an extra activity in the course, the rest of them showed no response toward this type of activity. Even though some students did not tweet during the period of studying the subjects of Parasitology, they are lucky to get grade $\mathrm{C}$ or $\mathrm{C}+$, and that because the marks of the activity corresponding only $20 \%$ of the total.

For using this activity just for two times during the years 2015 and 2016, that because the Parasitology course is considered as elective course for the students specialized in Zoology. The feedback from the followers of the account We_Love_Para was encouraging to continue in this activity in the future as well as the account is still active. They mentioned that it is useful account to know new information about the parasitic diseases and how to prevent themselves to be in contact with the sources of the parasitological infections. This Academic trial is considered superior all over the world, so we couldn't find other results to compare with them.

From our point of view, we found that Twitter application was useful academic social activity and considered as excellent tool for improving subjects learning as mentioned by Basu (2013). Also, we noticed that Twitter application could be highly useful and informative if it used well and correct as declared by Deloatch (2015).

In Conclusion the learning for Parasitology course was improved and most the Parasitology students were enthusiastic and well motivated. By using Twitter application for extra activity encourage that the social Media could be used usefully. In addition, there was positive feedback in the Saudi community and some student's level whose their marks were clearly increased. Finally and incredibly good scientific experience was gained for both the Parasitology girl students and their teacher as well. 


\section{REFERENCES}

[1] Anderson, D.M., \& Haddard, C.J. (2005). Gender, voice, and learning in online course environments. Journal of Asynchronous Learning Networks, 9 (1), 3-14.

[2] Barrett, E., \& Lally, V. (1999). Gender differences in an online learning environment. Journal of Computer Assisted Learning, 15, 48-60.

[3] Basu, S (2013) 10 amazing ways for teachers and Tutors to use Twitter in Education. http://www.makeuseof.com/tag/10-ways-to-use-twitter-in-education/

[4] Bianco, J.S. 2009. Social networking and cloud computing: Precarious affordances for the "prosumer". Women's Studies Quarterly, 37(1-2), 303-311.

[5] Dabbagh, N. \& Kitsantas, A. (2011) 'Personal learning environments, social media, and selfregulated learning: a natural formula for connecting formal and informal learning', The Internet and Higher Education, vol. 15, no. 1, pp. 3_8.

[6] Deloatch, P. (2015) 30 innovative ways to use twitter in the classroom http://www.edudemic.com/the-30-newestways-to-use-twitter-in-the-classroom/

[7] Gunawardena, C.N. (1995). Social presence theory and implications for interaction in and collaborative learning in computer conferences. International Journal of Educational Telecommunications 1(2/3), 147-166.

[8] Gunawardena, C.N., \& Zittle, F. (1997). Social presence as a predictor of satisfaction within a computer-mediated conferencing environment. The American Journal of Distance Education, 11(3), 8-26.

[9] Hall, R. (2009) 'Towards a fusion of formal and informal learning environments: the impact of the read/write web', Learning, vol. 7, no. 1, pp. 29_40.

[10] Junco, R., Heiberger, G. \& Loken, E. (2011) 'The effect of Twitter on college student engagement and grades', Journal of Computer Assisted Learning, vol. 27, no. 2, pp. 119_132.

[11] Kassens-Noor, E. (2012) 'Twitter as a teaching practice to enhance active and Informal learning in higher education: the case of sustainable tweets', Active Learning in Higher Education, vol. 13, no. 1, pp. 9_21.

[12] Kim, J., Kwon, Y., \& Cho, D. (2011). Investigating factors that influence social presence and learning outcomes in distance education. Computers \& Education, 57, 1512-1520.

[13] Lowenthal, P.R. (2009). Social presence. In P. Rogers, G. Berg, J. Boettcher, C. Howard, L. Justice, \& K. Schenk (Eds.), Encyclopedia of distance and online learning (2nd ed., pp. 1900-1906). Hershey, PA: IGI Global.

[14] Neo, T.-K., \& Neo, M. (2004). Classroom innovation: Engaging students in Interactive multimedia learning. The Campus-wide Information Systems, 21(3).

[15] Ory, J.C., Bullock, C., \& Burnaska, K. (1997). Gender similarities in the use of and attitudes about ALN in a university setting. Journal of Asynchronous Learning Networks, 1(1), 1-16.

[16] Palloff, R.M., \& Pratt, K. (2007). Building online learning communities. Effective strategies for the virtual classroom. San Francisco, CA: Jossey-Bass.

[17] Parry, D. (2008). Twitter for academia. Retrieved from http://academhack.outsidethetext.com/home/2008/twitter-foracademial.

[18] Quantcast. (2010). Twitter.com US demographics. Retrieved from http://www.quantcast.com/twitter.

[19] Rankin. M. (2009). Some general comments on the Twitter experiment. Retrieved from http://bit.ly/lOLjs

[20] Reed. P. (2013). Hashtags and retweets: using Twitter to aid Community,Communication and Casual (informal) learning. Research in Learning Technology Vol. 21 : 1-21.

[21] Richardson, J.C., \& Swan, K. (2003). An examination of social presence in online courses in relation to students' perceived learning and satisfaction. Journal of Asynchronous Learning Networks, 7(1), 68-88.

[22] Smith, J. (2010). December data on Facebook's US growth by age and gender: Beyond 100 million. Retrieved from http://www.insidefacebook.com/2010/01/04/december-data-onfacebook\%E2\%80\%99s-us-growth-by-age-andgender-beyond-100-million/.

[23] Somerville, M.M., and Brar, N. 2010. From information to learning commons: Campus planning highlights. New Library World, 111(5/6), 179 - 188.

[24] Tu, C.-H. (2002). The relationship between social presence and online privacy. Internet and Higher Education, 5, 293318.

[25] Wakefield, J.S., \& Warren, S.J. (2012). Learning and teaching as communicative actions: Social media as educational tool. In K. Seo (Ed), Using social media effectively in the classroom: blogs, wikis, Twitter, and more. Routledge/Taylor \& Francis.

[26] Wakefield, J. S., Warren, S. J., Alsobrook, M. (2011). Learning and Teaching as Communicative Actions: A MixedMethods Twitter Study. Knowledge Management \& E-Learning: An International Journal, Vol.3, No.4. : 563- 583. 
[27] Wenger, E. (2006). Communities of practice - A short introduction. Retrieved from http://www.ewenger.com/theory/communities_of_practice_intro.htm.
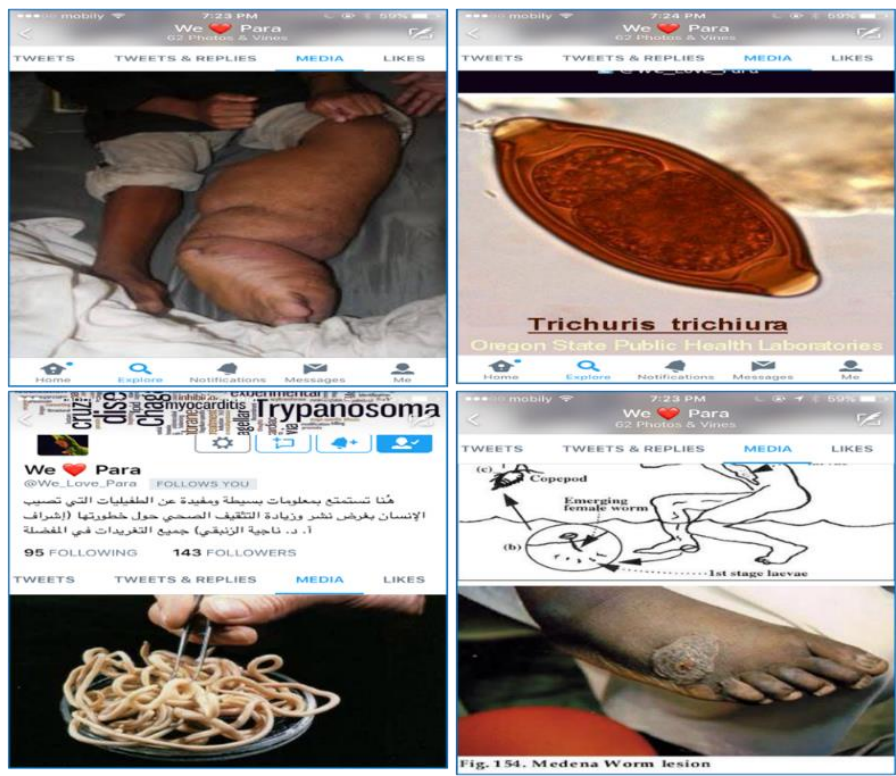

Fig 1: Twitter tweets for Parasitology students showing using Arabic language in the semesters 1st 2015 and 2nd 2016

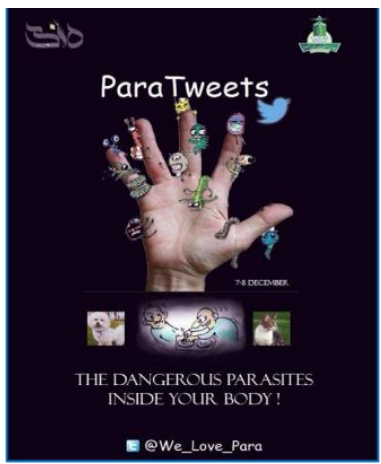

Fig 2: The educational exhibition banner for Parasitology girl students showing their effort during the semesters 1 st 2015 and 2nd 2016

\begin{tabular}{|c|c|c|c|c|c|c|c|}
\hline \multicolumn{4}{|l|}{1 st 2015} & \multicolumn{4}{|l|}{$2^{\text {nd }} 2016$} \\
\hline $\begin{array}{l}\text { Students Twitter } \\
\text { Accounts }\end{array}$ & $\begin{array}{l}\text { No. of } \\
\text { Tweets }\end{array}$ & $\%$ & $\begin{array}{l}\text { Students } \\
\text { Results }\end{array}$ & $\begin{array}{l}\text { Students Twitter } \\
\text { Accounts }\end{array}$ & $\begin{array}{l}\text { No. of } \\
\text { Tweets }\end{array}$ & $\%$ & $\begin{array}{l}\text { Students } \\
\text { Results }\end{array}$ \\
\hline @Student1 & 76 & 20.3 & $\mathrm{C}+(75)$ & @Student8 & 0 & 0 & $\mathrm{C}(70)$ \\
\hline @Student2 & 59 & 15.7 & $\mathrm{~B}+(85)$ & @Student9 & 28 & 7.5 & $\mathrm{D}(60)$ \\
\hline
\end{tabular}




\begin{tabular}{||l|l|l|l|l|l|l||}
\hline \hline @Student3 & 0 & 0 & $\mathrm{D}(60)$ & & \multicolumn{4}{||}{} \\
\hline @Student4 & 35 & 9.3 & $\mathrm{C}(70)$ & @ Teach_para & 64 & 17.1 \\
\hline @Student5 & 0 & 0 & $\mathrm{C}+(75)$ & @ Teach_pers & 43 & 11.5 \\
\hline @Student6 & 21 & 5.6 & $\mathrm{D}(60)$ & @Others & 38 & 10.1 \\
\hline
\end{tabular}

Table 1: Twitter accounts for Parasitology girl students showing the $\%$ of tweets in Twitter application and their results in the semesters 1 st 2015 and 2nd 2016

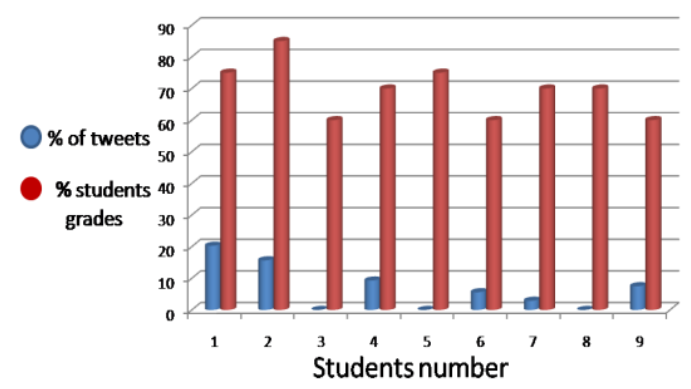

Fig 3: Twitter accounts for Parasitology girl students showing \% of tweets in Twitter application and their results in the semesters 1st 2015 and 2nd 2016

\begin{tabular}{||l|l|l|l||}
\hline $\begin{array}{l}\text { Categories of } \\
\text { Re-tweets }\end{array}$ & Percentage \% & $\begin{array}{l}\text { Categories of Liked- } \\
\text { tweets }\end{array}$ & Percentage \% \\
\hline$>\mathbf{4}=\mathbf{1 0 9}$ & 41.1 & $\mathbf{> 4}=\mathbf{2 1 5}$ & 62.9 \\
\hline $4-6=145$ & 54.7 & $4-6=125$ & 36.5 \\
\hline $7-9=9$ & 3.4 & $7-9=2$ & 0.6 \\
\hline$<9=2$ & 0.8 & $<9=0$ & 0 \\
\hline Total $=\mathbf{2 6 5}$ & 100 & Total $=\mathbf{3 4 2}$ & 100 \\
\hline
\end{tabular}

Table 2: Categories of Re-tweets and Liked-tweets from people in Twitter application for the Parasitological tweets in the course account in semesters 1st 2015 and 2nd 2016 


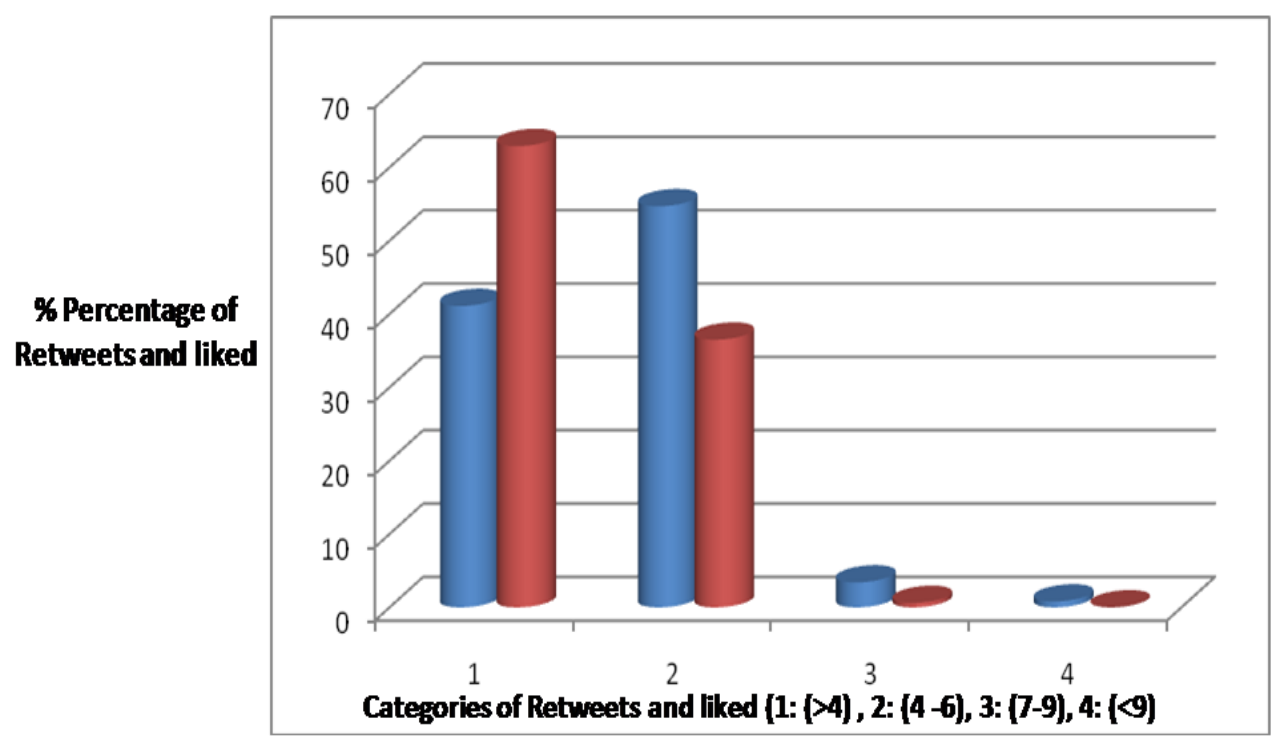

Fig 4: Categories of Re-tweets and liked-tweets (1: $(>4), 2:(4-6), 3:(7-9), 4:(<9)$ from people in Twitter application for the Parasitology tweets the course account in semesters 1 st 2015 and 2nd 2016

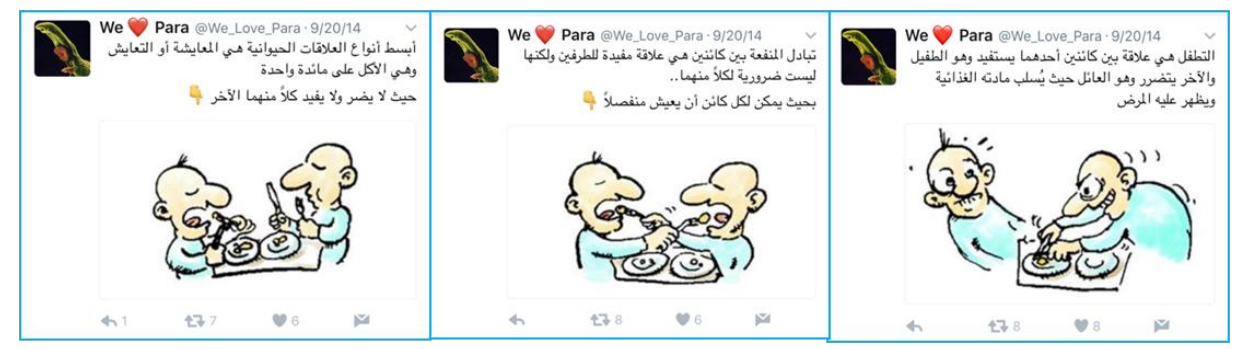

Fig 5: Three tweets were the most re-tweeted and liked-tweets by the others people in Twitter application which related to the categories of animal relationships 